\title{
The International and
}

\section{Comparative Law Quarterly}

(incorporating the Quarterly of the Society of Comparative Legislation and International Law and the Transactions of the Grotius Society)

\section{BOARD OF EDITORS}

\author{
General Editor: K. R. Simmonds \\ Assistant General Editor: TOM HARPER
}

P. B. Carter a A. K. R. Kiralfy

NORMAN S. MARSh 


\section{The International and Comparative Law Quarterly \\ \begin{tabular}{llll}
\hline Volume 26 & Part 2 & April 1977 \\
\hline
\end{tabular}}

\section{ARTICLES}

PAGE

Article 177 of the eEC Treaty in the Practice of National Courts Gerhard Bebr 241

Towards Integrated Management of International. Trade -The U.S. Trade Act 1974

Kazimierz Grzybowski, Victor Rud and George Stepanyenko

Apportionment of an International Common Petroleum DEPOSIT William $T$. Onorato

International Unitisation of an OfFshore Gas Field

J. C. Woodlitje

Protection of Property versus Protection of Commercial

Transactions in French and English Law

C. S. P. Harding and M. S. Rowell

COMPUlsory ARbitration and the Industrial COURT IN

Trinidad and Tobago $\quad R$. L. Chaudhary

The Law's Response to Marital Violence in ENGland aND THE U.S.A.

Susan Maidment 403

Young Persons in Conflict with the Law in Canada

Richard G. Fox

\section{SHORTER ARTICLES, COMMENTS AND NOTES}

Proposed EEC Regulation on the Control of Mergers Frans G. A. van Kraay 468

Vicarious Liability and the Conflict of Laws Lawrence Collins 480 


\section{CONTRIBUTIONS AND SUBSCRIPTIONS}

All correspondence, including books for review and business communications, as well as contributions (which must be typed), should be addressed as follows: The General Editor, International and Comparative Law Quarterly, British Institute of International and Comparative Law, Charles Clore House, 17 Russell Square, London WC1B 5DR (01 636 5802-3-4-5).

Subscriptions and Orders should be sent to the British Institute of International and Comparative Law, at the above address.

Contributions to the International and Comparative Law Quarterly express the views of their authors and not necessarily the views of the Editorial Board or of the British Institute of International and Comparative Law.

(1) 1977

The British Institute of International and Comparative Law 
